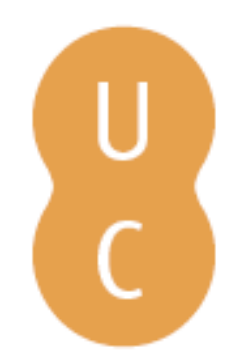

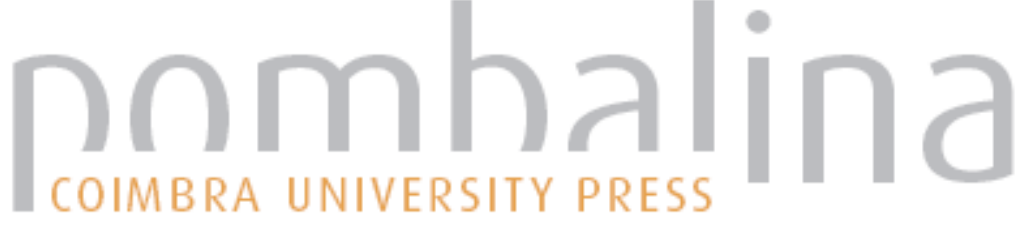

\section{Modelling of junction fires with analytical and numerical analysis of the phenomena}

Autor(es): $\quad$ Raposo, Jorge; Viegas, Domingos; Abouali, Abdelrahman; Rodrigues, André; Almeida, Miguel; André, Jorge; Xie, Xiaodong

Publicado por: Imprensa da Universidade de Coimbra

URL

persistente: URI:http://hdl.handle.net/10316.2/44578

DOI: $\quad$ DOI:https://doi.org/10.14195/978-989-26-16-506_61

Accessed : $\quad$ 26-Apr-2023 02:35:42

A navegação consulta e descarregamento dos títulos inseridos nas Bibliotecas Digitais UC Digitalis, UC Pombalina e UC Impactum, pressupõem a aceitação plena e sem reservas dos Termos e Condições de Uso destas Bibliotecas Digitais, disponíveis em https://digitalis.uc.pt/pt-pt/termos.

Conforme exposto nos referidos Termos e Condições de Uso, o descarregamento de títulos de acesso restrito requer uma licença válida de autorização devendo o utilizador aceder ao(s) documento(s) a partir de um endereço de IP da instituição detentora da supramencionada licença.

Ao utilizador é apenas permitido o descarregamento para uso pessoal, pelo que o emprego do(s) título(s) descarregado(s) para outro fim, designadamente comercial, carece de autorização do respetivo autor ou editor da obra.

Na medida em que todas as obras da UC Digitalis se encontram protegidas pelo Código do Direito de Autor e Direitos Conexos e demais legislação aplicável, toda a cópia, parcial ou total, deste documento, nos casos em que é legalmente admitida, deverá conter ou fazer-se acompanhar por este aviso.

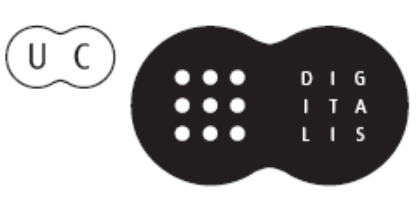




\section{ADVANCES IN}

\section{FOREST FIRE RESEARCH}

\section{8}

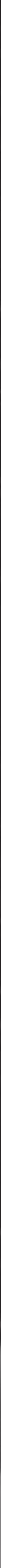




\title{
Modelling of junction fires with analytical and numerical analysis of the phenomena
}

\author{
Jorge Raposo*1,2 ${ }^{*}$ Domingos Viegas ${ }^{1,2}$; Abdelrahman Abouali ${ }^{1}$; André Rodrigues ${ }^{1}$; Miguel \\ Almeida ${ }^{1}$, Jorge André, J. ${ }^{2}$; Xiaodong $\mathrm{Xie}^{3}$ \\ ${ }^{1}$ Association for the Development of Industrial Aerodynamics. Rua Pedro Hispano, $n^{\circ} 12,3030$ - \\ 289 Coimbra, Portugal, \{jorge.raposo@dem.uc.pt*\} \\ ${ }^{2}$ University of Coimbra, Rua Luís Reis dos Santos, Coimbra 3030-788, Portugal \\ ${ }^{3}$ State Key Laboratory of Fire Science, University of Science and Technology of China, Hefei, \\ China
}

\begin{abstract}
The concept of junction fires was introduced in Viegas et al. 2012, as two approaching lines of fire, making a small angle between them. In the approach, the fires interact and induce convective flows that modifies the fire behaviour mainly its rate of spread. This process induces very strong fields of vorticity, high rates of fire spread or a large number of spot fires. Since the beginning, an exhaustive parametric study of the phenomena of the junction fires was carried out. Results from laboratory and field-scale experiments, using various fuel beds and slope angles and from large-scale fires show that the processes are similar at a wide range of scales with little dependence on the initial boundary conditions. These results correspond to a large amount of data collected. With this data, a generalization of phenomena for different conditions was made through semiempirical models that can predict with a good agreement the sudden evolution of the rate of spread of the fire front, which results of the interaction of the fire lines, as function of the independent parameters namely time $\mathrm{t}$, distance $\mathrm{x}$, slope a and initial angle between the fire fronts. In addition, an effort to simulate the evolution of this kind of fires using CFD based numerical models was performed.
\end{abstract}

Keywords: fire behaviour; extreme fire behaviour; dynamic fire behaviour; accelerating fires; merging fires;

\section{Introduction}

The concept of junction fires was introduced in Viegas et al. 2012, when two approaching lines of fire make a small angle between them. In the approach, the fires interact and induce convective flows that modify the fire behaviour, mainly its rate of spread (ROS). This process induces very strong fields of vorticity, high rates of fire spread or a high number of spot fires. Since the beginning, an exhaustive parametric study of the phenomena of the junction fires was carried out. The results from laboratory and field-scale experiments, using various fuel beds and slope angles and from large-scale fires show that the processes are similar at a wide range of scales with little dependence on the initial boundary conditions. To characterize the effects of wind on junction fires, a set of experimental tests were performed, in CEIF's wind tunnel, using pine needles (Pinus pinaster), varying wind speed between 1 and $5 \mathrm{~m} / \mathrm{s}$

\section{Problem analysis}

The characteristics of a junction fire and IR images of various stages of its development were presented in Viegas et al. (2012) and in Viegas et al. (2013). In these studies, it was confirmed that two fire fronts merge at the intersection point D. A very complex and dynamic set of processes starts to develop in which the geometrical and physical properties of the fire fronts change continuously. A unique feature of this fire is the rapid advance of point $\mathrm{D}$ that causes the triangular shaped fuelbed to 
burn, maintaining its general shape but with increasing values of $\theta$. The rapid acceleration of the fire front near $\mathrm{D}$ caused by the convective flow induced by the fire is like the eruptive fire behaviour. Unlike the eruptive fire in a canyon (cf. (Viegas and Pita 2004); (Viegas 2006); (Viegas and Simeoni 2011)), the rate of spread increase has a break as if the fire and the mechanisms that support its acceleration are reduced and then undergo an inversion in their contributing effects. In this article one analysed the problem of junction fires under the wind effect, considering that the phenomena of junction fires under the effect of the slope was already addressed in previous works as well the effect of fuels and scale. The interaction between wind and slope can produce a set effects on the fire propagation. (Sharples et al. 2012). Commonly it is stated that the wind has a similar effect in the slope during the fire propagation, with the difference that the wind can achieve higher intensity compared with the slope (Viegas 1998). Several times the fire propagation is driven by the slope and wind together as referred in (Viegas 2004) Nevertheless it is common to study separately each factor, as it will be done in this article, here the focus is on the effect of wind. One of the firsts studies about the role of the wind in the forest fires was carried out by (Grumer and Strasser 1965), in the work it was proved trough laboratorial experiments that large scales fires rise with winds able of increasing the burning rate similar to firestorms. Rothermel (1972) proposed a model that includes the contribution of wind and slope in the fire propagation trough out adimensional coefficients. Morandini et al. (2006) investigated the effects of wind on the properties of a fire front, using Mediterranean shrubs as fuel. Sharples et al. (2010) study fire behaviour in atypical situations due to the interaction of wind and topography with fire. In the work (Viegas et al. 2012) is presented a general law of behaviour for junction fires. It was observed that the junction fires follow a pattern of evolution characterized by an acceleration phase, that persists during a certain time $t_{M}$, until achieve the maximum $\operatorname{ROS}\left(\mathrm{R}_{\mathrm{M}}\right)$ followed by a deceleration phase, as presented in figure 1

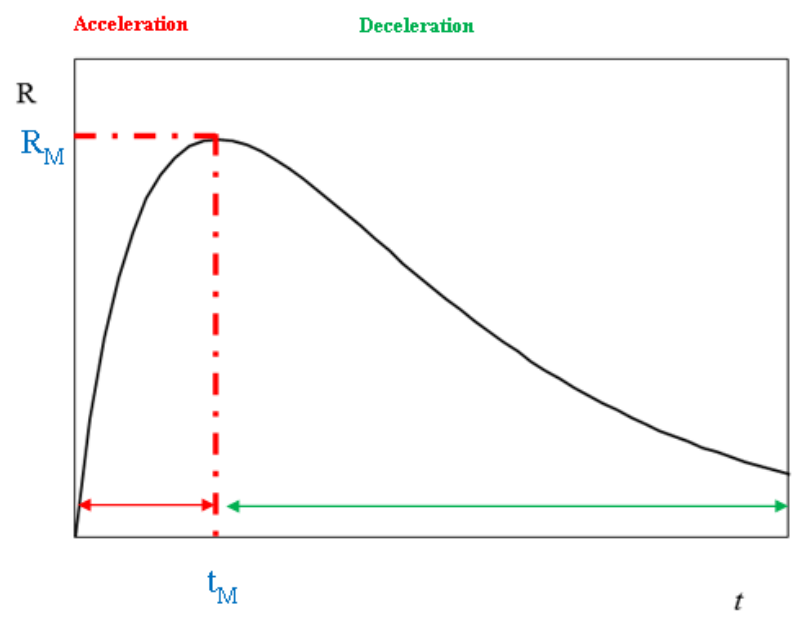

Figure 1 - Pattern of evolution of a junction fire

In (Raposo et al. 2018) general empirical laws of fire behaviour, which can be used to predict the evolution of a junction fire episodes, namely the evolution of non-dimensional rate of spread as a function of the independent slope angle $\alpha$ and angle between fire fronts $\theta_{\mathrm{o}}$ were presented. The same kind of analysis will be used for the tests with wind relating the different wind speeds with the evolution of the ROS.

\section{Methodology}

The tests were performed in the wind tunnel of LEIF. An image of the equipment can be observed in the figure 2.

Advances in Forest Fire Research 2018 - Page 550 


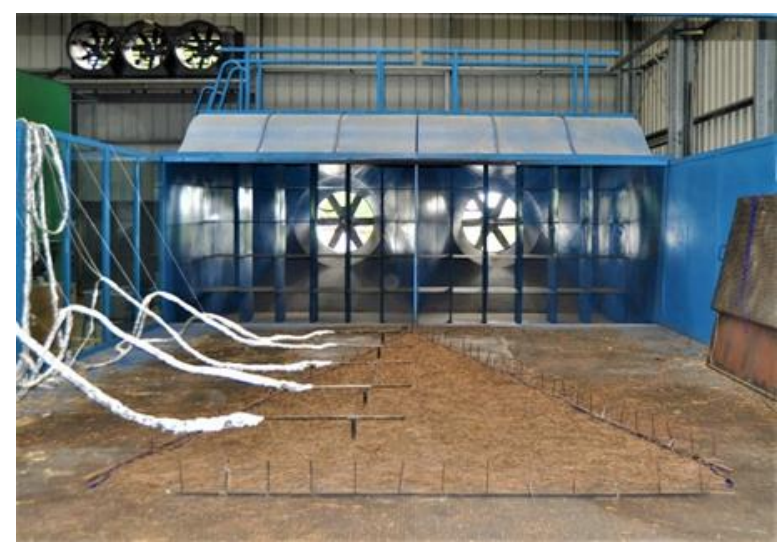

Figure 2 - wind tunnel of LEIF

In all of the tests dead pine needles of Pinnus Pinaster (PP) were used as fuel bed with a load of 0.6 $\mathrm{kg} / \mathrm{m}^{2}$, the wind speed experiments were $1,2,3,4$ and $5 \mathrm{~m} / \mathrm{s}$. Below is presented a table with the set of tests performed with an alphanumeric code to identify them, the first numeric digit refers to the order of realization of the test and the second digit is referred to the wind speed in $\mathrm{m} / \mathrm{s}$. They were randomly performed to avoid some bias in the data.

Table 1 - Set of tests performed

\begin{tabular}{|c|c|c|c|c|c|}
\hline Ref. & Designation & $\begin{array}{c}\text { Wind Speed } \\
\mathrm{m} / \mathrm{s}\end{array}$ & Fuel & $\alpha$ & $\theta$ \\
\hline 1 & CFW1-1 & 1 & \multirow{7}{*}{ PP } & \multirow{7}{*}{0} & \multirow{7}{*}{30} \\
\hline 4 & CFW4-1 & 1 & & & \\
\hline 2 & CFW2-2 & 2 & & & \\
\hline 5 & CFW5-3 & 3 & & & \\
\hline 3 & CFW3-4 & 4 & & & \\
\hline 7 & CFW7-4 & 4 & & & \\
\hline 6 & CFW6-5 & 5 & & & \\
\hline
\end{tabular}

To prepare the fuel bed in a V shape auxiliary lines were placed in the base of the wind tunnel demarking the shape of the fuel bed with $5 \mathrm{~m}$ length and a base of $2.68 \mathrm{~m}$, so that the angle of $30^{\circ}$ of angle between the fire fronts desired for the tests was respected.

The moisture content of the fuel $\left(\mathrm{m}_{\mathrm{f}}\right)$ was always registered as well as the values of the relative humidity and temperature of the air. The ignition of the fuel bed was made using two wool string lines sucked in a mixture of gasoline and diesel to ensure an instantaneous ignition. After the ignition the funs of the wind tunnel were turned on to set the wind speed. In every test, the spatial distribution of the temperature along with the fuel-bed infrared images were recorded, using an infra-red camera FLIR ThermaCam SC640. The acquisition rate was also 7Hz, the presence of the fire front was considered for values of temperature above $350^{\circ} \mathrm{C}$, which was considered a sign of the existence of flame in the place or time of measurement. Using IR methodology, the position of the fire perimeter at given time frames was assessed and from these images the ROS at various positions of the fire perimeter namely at point $\mathrm{D}$ was measured.

\section{Results and discussion}

From the tests performed in the experimental program the following data of the rate of spread of the fire front in the interception point was plotted for the five different wind speeds used. Also, a test performed with no slope and no wind in a V shape configuration was plotted together. 


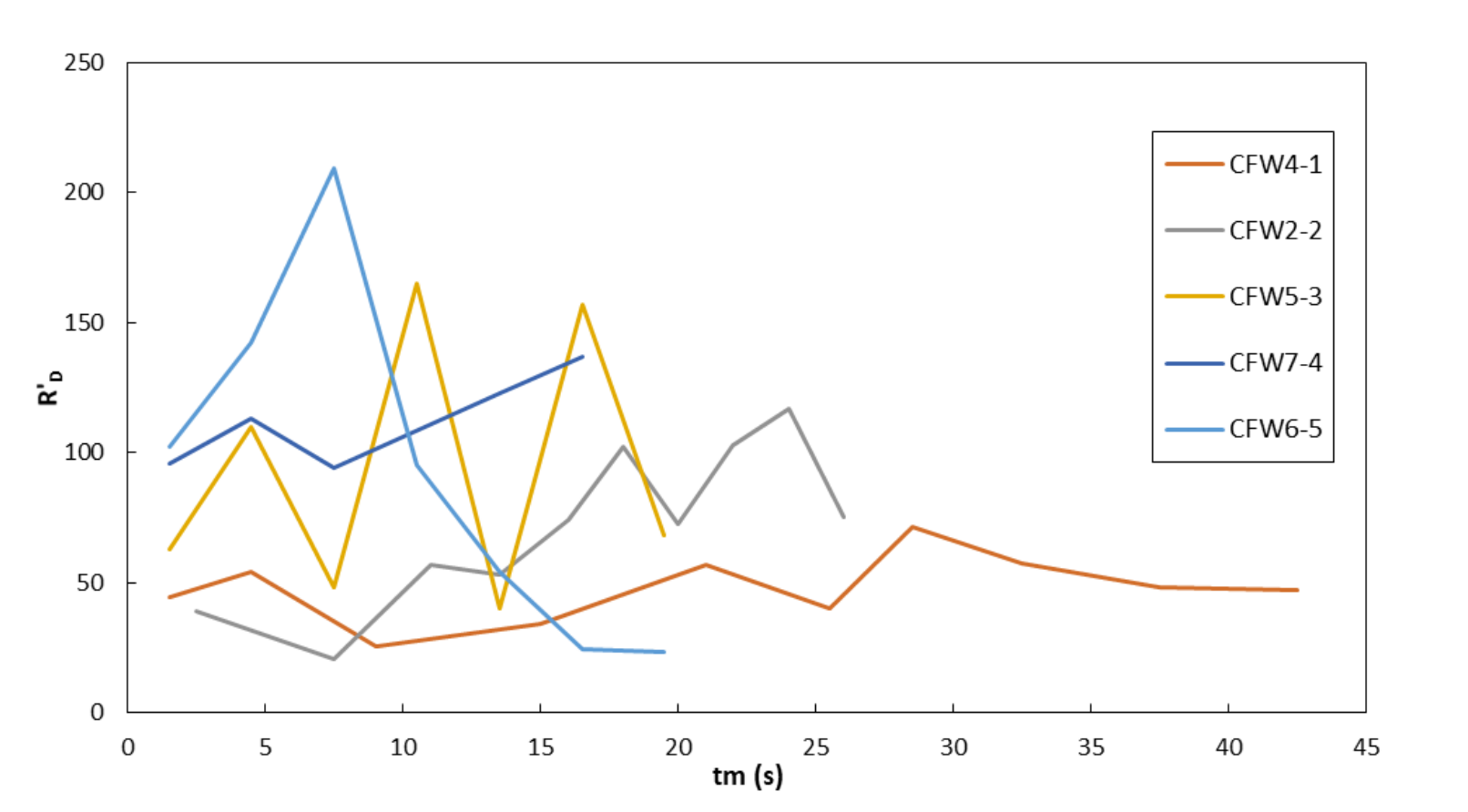

Figure 3 - ROS R'D as function of time, for the tests with wind and no slope

From the figure one can observe that the higher the wind speeds, the faster is the duration of the test until the complete burnt of the fuel bed, meaning that the average ROS in the intersection point D increases with the increase of wind speed.

The tests CFW3-4 and CFW1-1 were not used due to problems in their analysis.

Also, the tendency of the evolution of the ROS is of increasing with the differences between acceleration and deceleration phases, becoming less evident with the increasing of the wind speed, with exception of the test CFW6-5,

The data also allows to say that in the presence of wind the deceleration phase loses expression giving space to almost only a continuous acceleration of the fire. The explanation to this can be given by the fact that the introduction of the forced convection of the wind can overlap the natural buoyancy convection induced by the fire itself in a junction fire phenomenon. By the analysis of the plot, it is also possible to affirm that the maximum value of the ROS increases with the increase of the wind speed.

In figure 4 is showed the evolution of the ROS R'D as function of the distance $\mathrm{x}_{\mathrm{D}}$. From the plot is observed that the distance of occurrence of the maximum ROS increases with the increase of the wind speed. The rate of variation of the maximum ROS from the test with $1 \mathrm{~m} / \mathrm{s}$ relatively to the test with $2 \mathrm{~m} / \mathrm{s}$ is considerably bigger than the increase from the tests with $2 \mathrm{~m} / \mathrm{s}$ to $4 \mathrm{~m} / \mathrm{s}$ which indicates a kind of saturation level of the effect of the wind in the propagation of a junction fire. 


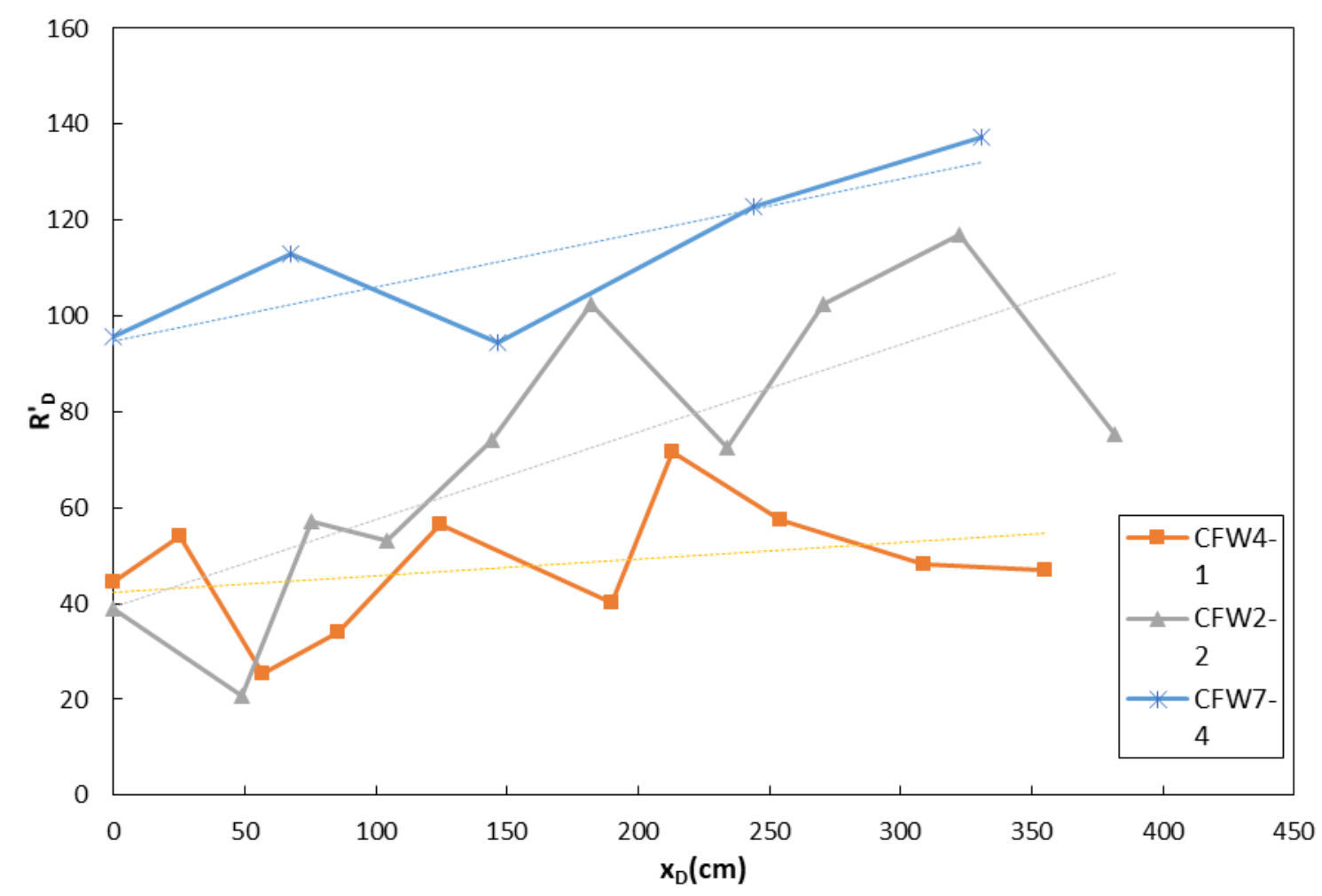

Figure 4 - ROS $R^{\prime}{ }_{D}$ as function of the distance $x_{D}$.

\section{Conclusion}

This is a preliminary study about the wind effect on the phenomena of the junction fires with a limited number of tests performed. Nevertheless, from the data obtained they seem to indicate that the maximum ROS of a junction fire increases with the increase of the wind speed until to a threshold value, that demands a more exhaustive work for its definition, but clearly it is observed by the saturation of the increment of the ROS as result of the rise of the wind speed.

\section{Acknowledgements}

This work was prepared under the framework namely of projects "Firewhirl - Vorticity Effects in Forest Fires" (Ref. PTDC/EMS-ENE/2530/2014), financed by national funds through the Portuguese Foundation for Science and Technology - FCT and project "Firextr - Prevent and prepare society for extreme fire events: the challenge of seeing the "forest" and not just the "trees" (Ref: PTDC/ATPGEO/0462/2014), co-financed by the European Regional Development Fund (ERDF) through the COMPETE 2020-Operational Program Competitiveness and Internationalization (POCI Ref: 16702) and national funds by FCT-Foundation for Science and Technology. It was also prepared under the framework of Projects "Fireprotect - Protection Systems for the protection of persons and elements exposed to the fire", Region (Centro 2020, Centro-01-0246-FEDER-000015) and project "ReNATURE - Valorisation of the Natural Endogenous Resources of the Centro Region" (Centro 2020, Centro-01-0145-FEDER-000007) supported by European Investment Funds by FEDER.)

The authors wish to thank their colleagues Luis Ribeiro and Nuno Luis for their support in the analysis of data and in the preparation of some work related with the article. 


\section{References}

Grumer J, Strasser A (1965) Uncontrolled fires - Specific burning rates and induced air velocities. Fire Technol ogy 1, 256-268.

Raposo J, Viegas DX, Xie X, Almeida M, Porto L, Sharples J, Figueiredo A (2018) Analysis of the physical processes associated to Junction Fires at Laboratory and Field Scales. International Journal of Wildland Fire.

Sharples JJ, McRae RHD, Wilkes SR (2012) Wind-terrain effects on the propagation of wildfires in rugged terrain: Fire channelling. International Journal of Wildland Fire 21, 282-296. doi:10.1071/WF10055.

Viegas DX (1998) Forest fire propagation. Philosophical Transactions of the Royal Society of London Series A: Mathematical, Physical and Engineering Sciences 356, 2907 - 2928.

Viegas DX (2004) Slope and wind effects on fire propagation. International Journal of Wildland Fire 13, 143-156. doi:10.1071/WF03046.

Viegas DX (2006) Parametric study of an eruptive fire behaviour model. Int. J. Wildl. Fire 15, 169177. http://dx.doi.org/10.1071/WF05050.

Viegas DX, Pita LP (2004) Fire spread in canyons. International Journal of Wildland Fire 13, 253 274. doi:10.1071/WF03050.

Viegas DX, Raposo JR, Davim D a., Rossa CG (2012) Study of the jump fire produced by the interaction of two oblique fire fronts. Part 1. Analytical model and validation with no-slope laboratory experiments. International Journal of Wildland Fire 21, 843-856. doi:http://dx.doi.org/10.1071/WF10155.

Viegas DX, Simeoni A (2011) Eruptive Behaviour of Forest Fires. Fire Technology 47, 303-320. doi:10.1007/s10694-010-0193-6. 